\title{
Perceptions of Unrestricted Gift Giving and the Integrity of Public Servants in Nigeria
}

\author{
Malachy Ogbonna Ugwu \\ Walden University \\ Mark Gordon \\ Walden University
}

\begin{abstract}
Public policy regulation in Nigeria allows public servants to accept gifts without restriction based on local culture. The purpose of this qualitative case study was to understand this cultural practice and its implications for the integrity of public servants. Using Mettler and SoRelle's conceptualization of policy feedback theory, the research questions focused on the perceptions of civic organization leaders on this cultural practice in relation to the integrity of high-level public servants in a region of Nigeria. Data were collected from 10 purposely selected public administrator leaders using open-ended, semistructured interview protocols, and an analysis of publicly available documents. The data were subjected to an inductive coding procedure followed by thematic analysis. Findings suggested that the perceptions of the cultural practice of unrestricted gift giving in the public service were negative and unethical. Consequently, the findings also suggested an amendment to the relevant sections of the Nigerian Constitution to provide for a restricted monetary value of gifts allowable in the public service. The implications for positive social change include a better understanding of ethics in public administration. Policy makers and practitioners can utilize findings to bring about ethical, effective, and efficient public service in Nigeria. Other nations can learn from the Nigerian experience of unrestricted gift giving in the public sector.
\end{abstract}

Keywords: gift giving, integrity, public administration ethics, policy regulation, corruption, public servants, civil society organizations

\section{Introduction}

The widely accepted cultural practice of unhindered gift giving in the public service of Nigeria, especially in a particular territory of the country, is viewed by some policy analysts as being contradictory to the fight against corruption and to the safeguarding of public servants' integrity (J. B. Bello \& Murtala, 2015; Markovska \& Adams, 2015; Szto, 2016).The 1999 Constitution of Nigeria (as amended), Fifth Schedule, Part 1 demands that public servants maintain a high standard of morality, transparency, and accountability in the conduct of government business. To this effect, Article 6(1) of the same Fifth Schedule restricts public officers from asking or accepting any property or benefit of any kind (i.e., a gift) either for themselves or any other person while discharging their duties. However, Part 1, Article 6(3) allows a public officer to accept such personal gifts or benefits from friends and relatives within the context of cultural practice. This provision is contradictory to the goal of fighting public sector corruption (A. O. Bello, 2014). It is, therefore, considered imperative that this policy guideline on unrestricted gift giving on cultural basis be reexamined through a qualitative case study to arrive at informed judgment and protect the public from unethical practice. 
According to Waziri (2010), Nigerian policy makers have implemented many policy options to fight corruption in the public sector, but such measures have been largely ineffective. These policy measures include Decree 54 of 1976 (Public Officer Investigation of Assets), Decree 53 of 1999 (Forfeiture of Assets Decree), the Failed Bank Tribunal Decrees of 1996, the Code of Conduct Bureau and the Code of Conduct Tribunal of 1979, and the 1999 amended Code of Conduct for Public Officers, Fifth Schedule, Part 1 of the Nigerian Constitution. Additional related policy measures include the Ethical Revolution of 1979-1983, the War Against Indiscipline of 1983-1985, the War Against Indiscipline and Corruption of 1993-1998, the Corrupt Practices and Other Related Offences Act of 2000 to date, and the Economic and Financial Crimes Commission of 2003 to date. Despite all these measures designed to curb corruption, "Nigeria is still rated one of the most corrupt countries in the world" (Ijewereme 2013, p. 39).

Researchers such as Kems and Wood (2015), Kim (2014), and Leisinger (2015) have examined the ethical as well as economic consequences of the practice of unfettered gift giving in the public sector. However, these researchers did not examine the appropriate use of policy instruments to control the cultural practice of unhindered gift giving in the Nigerian public sector and its implication for the public servants as trustees of the people. These researchers also did not investigate the view of leaders of civil society organizations (CSOs) on the practice of gifting in the public service even though they (the CSOs) are "one of the self-governing, opinion molders in our society that makes effective contributions in the policy process" (Hanf, 1978, p. 23; see also Benson, 1982).

\section{Purpose and Research Questions}

This study was intended to contribute to positive social change by providing empirical data that can help policy makers in Nigeria. Other counties may also learn from this study. The study is a practical case of implementing the policy feedback mechanism which is always needed in the policy process to guide policy makers on decision making concerning policy maintenance, sustenance, adjustment, or total reversal (Pierson, 1993).

This study provides insights about the perceptions of leaders of CSOs regarding the use of policy instruments to regulate the practice of unhindered gift giving in the public service of Nigeria. To achieve this purpose, we sought answers to the following questions:

Research Question 1: What are the perceptions of civil society organizational leaders about integrity and corruption in relation to unrestricted gift giving to federal public servants in Grade Level 15 and above?

Research Question 2: What do leaders of CSOs in Nigeria identify as issues related to the cultural practice of unrestricted gift giving to federal public servants in the referenced territory of Nigeria in Grade Level 15 and above?

Research Question 3: What do leaders of CSOs in Nigeria perceive may be fitting policies needed to address issues related to the cultural practice of unrestricted gift giving to federal public servants in the territory of Nigeria in Grade level 15 and above?

3.1: What do leaders of CSOs in Nigeria perceive may be appropriate policy recommendation(s) concerning the provision of the Fifth Schedule, Part1, Article 6(3) in the Nigerian Constitution?

3.2: What do leaders of CSOs in Nigeria perceive may be appropriate recommendation(s) for the allowable monetary value of gifts? 
Mettler and SoRelle's (2014) policy feedback theory grounded this study. We used a qualitative approach to explore the study phenomenon because the cultural practice of unobstructed gift giving and its implications for the integrity of public servants is relatively an unknown area in the social and behavioral science literature, based on our review of the literature.

\section{Background}

The appropriateness of the culturally approved practice of unobstructed gift giving in the public service of Nigeria in relation to safeguarding the honesty of the public servants has been an issue of debate among policy experts (A. O. Bello, 2014; Osipitan \& Oyewo, 1999). Gift giving in the public service creates an unfortunate opportunity for public sector employees (Jones \& Bezuidenhout, 2014; Okonkwo, 1992). It is also positively correlated to corruption (Mentoor, 2010). Unrestricted gift giving may lead to unrestrained abuse of public office, and according to the World Bank Group Enterprise Survey (2014) and Oarhe (2013), it is often carried out by higher ranking public officials

In 2009, Kellogg, Brown and Root, a U.S. business, committed a crime of giving bribe or gifts to the tune of $\$ 180$ million to high-ranking government officials in the Ministry of Petroleum Resources in Nigeria to be awarded a contract of $\$ 6$ billion and was consequently found guilty as charged by a court of competent jurisdiction (Global Witness, 2012). According to the Transparency International (2016) Corruption Perceptions Index, the worldwide corruption perceptions of the public sector of Nigeria for 2013-2016 were "highly corrupt." Similarly, Nigeria's gross domestic product per-capita income between 1960 and 2015 "was 20 percent of the world's average" (Trading Economics, 2017, p. 8). Despite its vast natural resources, Nigeria is rated as one of the poorest nations in the globe with more than $65 \%$ of its population living "below the poverty line" (Opejobi, 2016). Nigeria has a policy guideline that prohibits gift giving in the public sector, but the same policy regulation allows unhindered gift giving in the public sector for cultural reason as per the provisions of the 1999 Constitution of Nigeria (as amended) and the Code of Conduct Bureau and Tribunal Act, CAP 56, Laws of the Federation of Nigeria, 1990, and Independent Corrupt Practices and Other Related Offences Commission Act of 2000, among other extant regulations. The Fifth Schedule, Part 1, Articles 6(1)-(3) of the constitution (Constitution of the Federal Republic of Nigeria, 1999), for emphasis, stated that

(1) A public officer shall not ask for or accept any property or benefit of any kind for himself or any other person because of anything done or omitted to be done by him in the discharge of his duties.

(2) For the purpose of sub-paragraph '1' of this paragraph the receipt by a public officer of any gifts or benefits from commercial firms, business enterprises or persons who have contracts with the government shall be presumed to have been received in contravention of the said sub-paragraph unless the contrary is proved.

(3) A public officer shall only accept personal gifts or benefits from relatives or personal friends to such extent and on such occasions as are recognized by custom. (p. 207)

A. O. Bello (2014) described Article 6(3) as a window of opportunity for corruption as it is imprecise and irresponsive to addressing the problems related to the practice of unhampered gifting in the public sector.

The need to address the issues regarding the practice of unobstructed gift giving in Nigeria's public sector became necessary because the public service, according to J. B. Bello and Murtala (2015), is the bureaucracy that implements policies, programs, and projects of a country's government. 
According to Ayodele (2014), the public service is the service center that creates an enabling environment where individuals in all sectors of the economy can pursue their legitimate goals unfettered. In his book, Performance Measurement and Management, Ayodele listed the functions of the public service to include implementing and enforcing of socioeconomic and political policies of the government; zzdesigning and implementing the public service; safeguarding political and fiscal discipline and accountability; serving the populace in an ethical, equitable, just, democratic, and fair manner; monitoring and evaluation of the activities of organizations, both public, private, and nongovernmental that render services on behalf of the government; and propelling development initiatives of the government.

Considering the central place of the public service in the life of a nation-state, public officers should be guided by a code of conduct that will enable them to be trustworthy and meet the expectation and confidence of the public. In Nigeria, the need to strengthen the existing modalities for monitoring the activities of public officers to bring them in tandem with the highest standards of public morality and accountability was the basis for the establishment of the Code of Conduct Bureau as well as the Code of Conduct Tribunal with legitimate powers to enforce the code of conduct for public officers (see Fifth Schedule, Section 1 of the Constitution of the Federal Republic of Nigeria, 1999, as amended). All this notwithstanding, Mentoor (2010) stated that permissible gifting in the public service on the ground of cultural practice is a negation of the government efforts to stamp out corruption in the public service.

In our study, we investigated the perceptions of leaders of CSOs on the use of policy instrument to govern the prevailing "license" to unfettered gift giving in the public sector of Nigeria in relation to protecting the integrity of public servants. Oriented towards evaluating public policy as a "system of courses of action, regulatory measures, laws, and funding priorities concerning a given topic promulgated by a government entity or its representation" (Cohen, 2012, p. 6), it was hoped that a critical evaluation of the existing policy on unrestricted gift giving in the public service might reveal issues that promote corruption in the public service and impact negatively on the honesty of the public servants.

According to Cohen (2012), public policy is a dynamic, complicated and interactive system of identifying and solving public problems. Consequently, questions guiding this study were targeted at seeking the perceptions of leaders of CSOs on the appropriateness of the current policy and recommendations to address issues that might negatively impair the realization of an effective, efficient and ethical public service. Public policy initiatives, explained Cohen (2012) and Pierson (1993), can solve identified human problems by evolving new policy guidelines or by reforming a subsisting policy to make it more efficient and effective.

The study helped to understand better the underlining contexts under which this case of cultural practice of unrestricted gift giving in the public service of a major territory in Nigeria was sustained even in the midst of the devastating effects of corruption in the public service of Nigeria as reported by A. O. Bello (2014), Global Witness (2012), Kim (2014), Markovska and Adams (2015), and Okonkwo (1992). Using a qualitative case study to review the research interest as undertaken by this study was in line with the aims and objectives of policy analysis that, according to Mazmanian and Sabatier (1983), include the following:

1. To derive the importance of policy analysis in contributing to determine, study, and assess public problems, policy performance, and policy prescription and advocacy;

2. To contribute to improved policy implementation and performance;

3. To understudy problems associated with a given policy and be guided on the determination of the required changes, modification, techniques, and other strategic 
steps that could be taken to address the identified problems and enhance its performance.

\section{Method}

\section{Materials and Procedure}

A qualitative case study guided the research design because qualitative paradigm is an appropriate method to explore a relatively unknown area. Data were collected from CSOs whose leaders met the following criteria:

1. Accreditation: Leaders whose CSOs were registered by the Bureau of Public Procurement (2007), which implied that they belonged to government-recognized CSOs and had operated within for the past 10 years (in Nigeria, the Bureau of Public Procurement is charged with the responsibility of accrediting CSOs for monitoring procurement processes and bid opening by the federal government agencies)

2. Office location and operation: Leaders whose CSOs had their offices located in the referenced territory in Nigeria and were operating in the territory, which suggested they were conversant with the research setting

3. Length of operation in the territory: Leaders who had been serving in their various organizations for the past 10 years, which suggested they might be conversant with the nature of gift giving practice in the research setting

4. Mission statements or advocacy thrusts: Leaders whose CSOs had their mission statements or advocacy thrusts slanted toward anticorruption, transparency, and good governance in the public service, which suggested they might discuss the research interest with ease

5. Independent funding: Leaders whose CSOs were not dependent on Nigerian government for funding, which suggested they might bare their minds on the research interest without hesitation

The study used qualitative data collection processes such as interviews and observational field notes, as well as analysis of relevant documents.

\section{Results}

The specific codes, categories, and themes that emerged from the data are as shown in Table 1.

\section{Emergent Theme 1: Perceptions of the Cultural Practice of Unrestricted Gift Giving}

The results interpreted from the conceptual summaries of the perceptions of the practice of unrestricted gift giving and integrity of public servants in a particular territory in Nigeria (see Table 2) centered on participants' responses to the question seeking their views on the cultural practice of unrestricted gift giving and integrity of public servants in the referenced territory. Leaders of CSOs mentioned the theme "perceptions of the cultural practice of unrestricted gift giving" 25 times during interviews and responses to questions, as indicated in Table 2. Relying on the coded responses of the leaders of the CSOs and the subthemes that emerged (i.e. positive and ethical, and negative and unethical), the frequency of responses was calculated to determine the dominant perceptions. 
Table 1. Research Questions, Categories of Perceptions, Number of Occurrences, and Emergent Themes

\begin{tabular}{|c|c|c|}
\hline $\begin{array}{l}\text { Categories of } \\
\text { Perceptions }\end{array}$ & $\begin{array}{c}\text { Occurrence, } \\
n\end{array}$ & Emergent Subthemes \\
\hline \multicolumn{3}{|l|}{ Research Question 1} \\
\hline $\begin{array}{l}\text { Perceptions of the } \\
\text { practice of gift } \\
\text { giving generally }\end{array}$ & 25 & Positive and ethical; negative and unethical \\
\hline \multicolumn{3}{|l|}{ Research Question 2} \\
\hline $\begin{array}{l}\text { Perceptions of the } \\
\text { nature of } \\
\text { association } \\
\text { between } \\
\text { unrestricted } \\
\text { public service gift } \\
\text { giving and } \\
\text { integrity }\end{array}$ & 36 & Favorable and unfavorable \\
\hline \multicolumn{3}{|l|}{ Research Question 3} \\
\hline $\begin{array}{l}\text { Perceptions of } \\
\text { effects of the } \\
\text { practice of gift } \\
\text { giving }\end{array}$ & 29 & $\begin{array}{l}\text { Lowering productivity or not; impairing national security } \\
\text { or not; promoting mediocrity or not; affecting ethical } \\
\text { content of an organization or not; providing window of } \\
\text { opportunity for corruption or not }\end{array}$ \\
\hline \multicolumn{3}{|l|}{ Research Questions } \\
\hline \multicolumn{3}{|l|}{3.1 and 3.2} \\
\hline $\begin{array}{l}\text { Perceptions of } \\
\text { Policy } \\
\text { recommendations }\end{array}$ & 30 & $\begin{array}{l}\text { Amendment of the constitution for outright removal of } \\
\text { the Fifth Schedule, Article 6(3); no amendment or } \\
\text { maintenance of the status quo so that the unrestricted } \\
\text { gift giving constitutional provision subsists; amendment } \\
\text { of the constitution for a restricted monetary value of } \\
\text { gift } 100 \text { - } \$ 2000 \text {; } 100 \text { - } \$ 5,000 \text {, or } \$ 5,100 \text { - } 10,000\end{array}$ \\
\hline \multicolumn{3}{|r|}{ 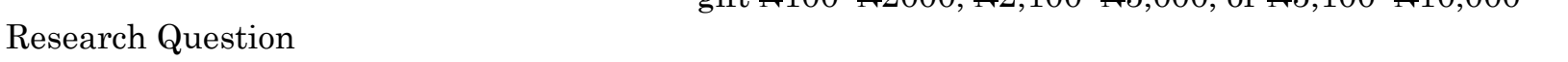 } \\
\hline \multicolumn{3}{|l|}{3.2} \\
\hline $\begin{array}{l}\text { Perceptions of } \\
\text { policy } \\
\text { recommendations } \\
\text { for constitutional } \\
\text { amendment }\end{array}$ & 25 & $\begin{array}{l}\text { Amend constitutional provision for outright removal of } \\
\text { Fifth Schedule, Article 6(3); amend the constitution for } \\
\text { a restricted monetary value; no amendment whatsoever }\end{array}$ \\
\hline \multicolumn{3}{|l|}{ Research Question } \\
\hline $\begin{array}{l}\text { Perceptions of } \\
\text { policy } \\
\text { recommendation } \\
\text { for restricted } \\
\text { monetary value of } \\
\text { gifts }\end{array}$ & 24 & $¥ 100-\$ 2,000 ;$ \\
\hline
\end{tabular}

\section{Perceptions of Practice}

Public service ethics of gift giving is found to be positively correlated to corruption (A. O. Bello, 2014; Dion, 2013; Hansen, 2012; Jones \& Bezuideulont, 2014). Reviewed literature also reports that public service gift giving practice on cultural ground is associated with the practice of cultural relativism which is as unethical and negative as it leads to ethical failure (Nepal, 2014). The literature also 
reports that successive leaderships of Nigeria lack the political will to implement antiethical policies in its public sector (Ijewereme, 2015). Consequently, corruption in Nigerian public sector needs to be addressed through stringent legislation, attitudinal change, encouragement of the activities of the civil societies or NGOs, and the press as well as good governance (A. O. Bello, 2014; Ijewereme, 2015; Krambia-Kapandis, 2014; Moon, 2016). The subtheme of positive and ethical perceptions of the cultural practice of unrestricted public service gifting is in sync with the report of Leisinger (2015), in which he advocates for the sustenance of public sector gifting as a way of immortalizing the timehonored tradition of hospitality and care with which majority of African nations are known for.

Table 2. Frequency of Perceptions of Practice of Unrestricted Gift Giving and Integrity of Public Servants

\begin{tabular}{lcc}
\hline & \multicolumn{2}{c}{ Perceptions } \\
\cline { 2 - 3 } Subtheme & $\boldsymbol{n}$ & $\%$ \\
\hline Positive and ethical & 8 & 30 \\
Negative and unethical & 17 & 70 \\
Total & 25 & 100 \\
\hline
\end{tabular}

\section{Emergent Theme 2: Perceptions of the Nature of Association Between Gift giving and Integrity}

Participants' responses yielded two subthemes: favorable association and unfavorable association. There were 36 mentions from participant interviews containing the theme "perceptions of the nature of association between gift giving and integrity." Thirty percent of the participants representing 11 mentions of the theme viewed the association between gift giving and integrity as "favorable," while $70 \%(n=25)$ of mentions of the theme viewed the association as "unfavorable."

The perceptions of the nature of association between gift giving and integrity of the public servants has attracted a number of research attentions. Oyamada (2015) perceived gifting in the public service as irresistible bait for corruption that negatively affects the integrity of the public servants. Ejiofor (1985) stated that integrity is the substructure upon which effective service delivery in the public service stands, adding that without integrity, public service would continue to suffer a compromised integrity. It is noted that the worst enemy of the public is a corrupt public servant (Ejionye, 1984).

\section{Emergent Theme 3: Perceptions of Effects of the Practice of Unrestricted Gift Giving}

Participants' responses were diverse and yielded 10 subthemes of lowering productivity, not lowering productivity, impairing national security, not impairing national security, promoting mediocrity, not promoting mediocrity, affecting the ethical content of an organization, not affecting the ethical content of an organization, providing window of opportunity for corruption, and not providing window of opportunity for corruption. There were 29 mentions from participant interviews containing the theme "perceptions of effects of the practice of unrestricted gift giving."

A full $70 \%$ of participants discussed lowering productivity, impairing national security, promoting mediocrity, negatively affecting ethical content of an organization, and providing window of opportunity for corruption, while $30 \%$ perceived it on the contrary. A respondent from the dominant $70 \%$ said, 
irrespective of grade levels, my perception is that it compromises the integrity of public servants; leads to bureaucratic red-tape and inefficiency; promotes ill-discipline, cronyism and stagnation; provides the license for fraud and corruption; destroys traditional societal values; short-changes the employers; contributes largely to economic melt-down and social crises and leads to unemployment and crime.

Conversely, one of the less dominant 30\% participants was of the view that Nigerians are hospitable and caring people and gift giving is one of such hospitalities, adding that a corrupt public servant can be corrupt without receiving gifts. However, David and Aidant (1992) contended that if the main sector of government set out for the implementation of public policy is adversely affected from discharging its duties efficiently and effectively by an "undue influence," it means recourse to public market failure.

\section{Emergent Theme 4: Perceptions of Policy Recommendations for the Practice of Unrestricted Gift giving}

From the conceptual summaries of the above theme bordering on perceptions of policy recommendation for the practice of unrestricted gift giving and integrity of public servants in a major territory in Nigeria, we interpreted the result of the participants' responses. Participants mentioned the above theme 30 times during interview and responses as indicated in the Table 3 and Figure 1. Relying on the coded responses of the participants, five subthemes emerged. The display of the overview of the sub-themes and their frequencies are hereby presented.

Table 3. Overview of Participants' Policy Recommendations

\begin{tabular}{|c|c|c|}
\hline \multirow[b]{2}{*}{ Subtheme } & \multicolumn{2}{|c|}{ Perceptions } \\
\hline & $n$ & $\%$ \\
\hline $\begin{array}{l}\text { Amendment of the constitution } \\
\text { for outright removal of the } \\
\text { Fifth Schedule, Article } 6(3)\end{array}$ & 3 & 10 \\
\hline $\begin{array}{l}\text { No amendment or maintenance } \\
\text { of the status quo so that the } \\
\text { unrestricted gift giving } \\
\text { constitutional provision } \\
\text { subsists }\end{array}$ & 9 & 30 \\
\hline $\begin{array}{l}\text { Amendment of the constitution } \\
\text { for a restricted monetary value } \\
\text { of gift of } 100-2000\end{array}$ & 3 & 10 \\
\hline $\begin{array}{l}\text { Amendment of the constitution } \\
\text { for a restricted monetary value } \\
\text { of gift of } 2,100-05,000\end{array}$ & 6 & 20 \\
\hline $\begin{array}{l}\text { Amendment of the constitution } \\
\text { for a restricted monetary value } \\
\text { of gift of } \$ 5,100-10,000\end{array}$ & 9 & 30 \\
\hline Total & 30 & 100 \\
\hline
\end{tabular}




\section{Emergent Theme 4.1: Perceptions of Participants' Policy Recommendations for the Amendment of the Fifth Schedule, Article 6(3) of the Nigerian Constitution (1999, as amended)}

From the available data on subtheme of "policy recommendations" as shown in Table 3 and the Figure 1, it could be seen that out of 10 participants, seven recommended several scopes of amendments ranging from outright removal of the constitutional provision (i.e. Fifth Schedule, Article 6[3], to restriction of monetary value of gifts to specified sums of money; while three participants recommended no amendment or maintenance of the status quo. This resulted in $70 \%$ support for constitutional amendment and 30\% opposed to amendment.

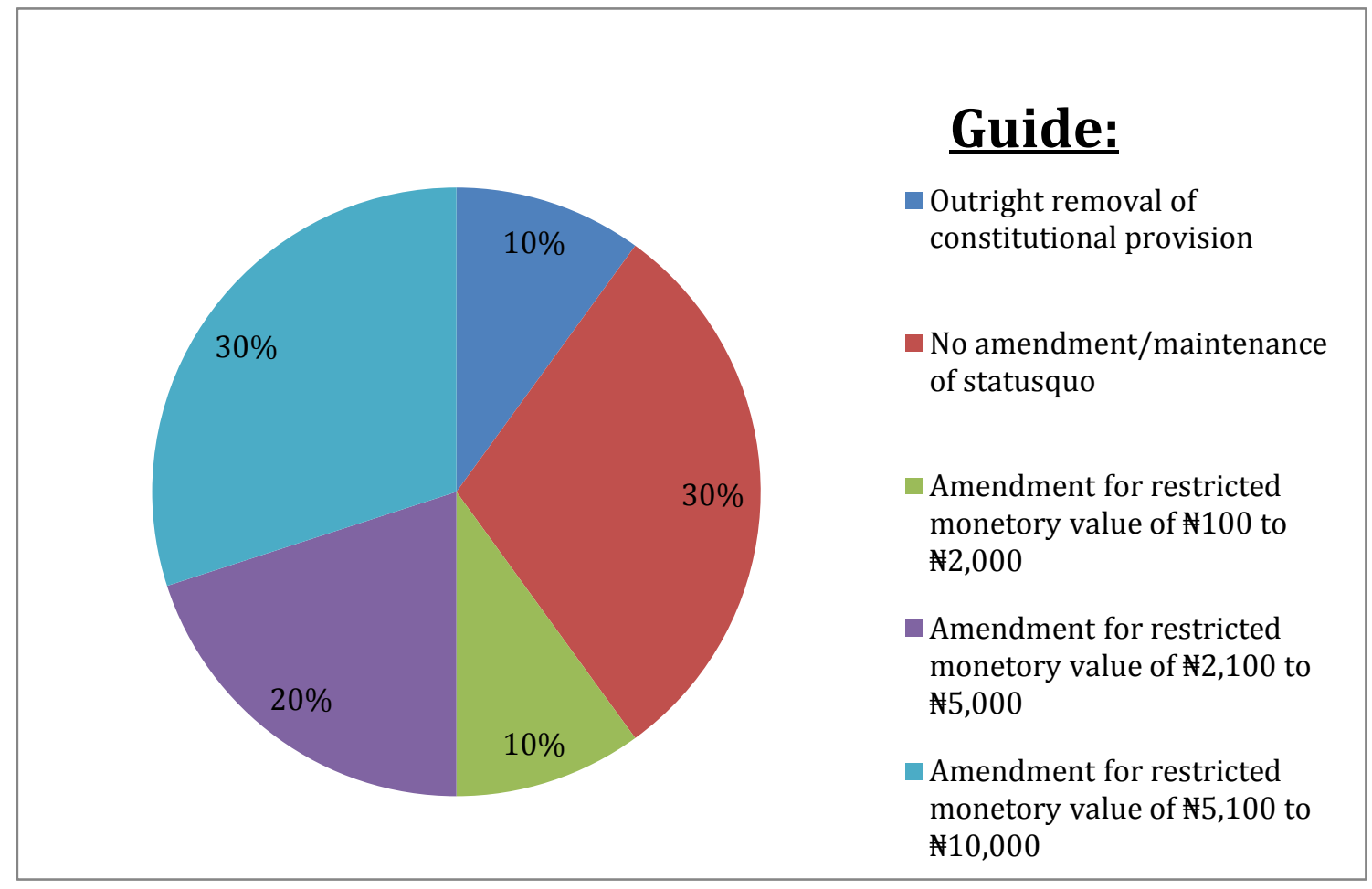

Figure 1. Visualization of Participants' Policy Recommendations

\section{Emergent Theme 4.2: Perceptions of Participants' Policy Recommendations for Allowable Monetary Value of Gifts}

Drawing from the data shown in Table 3 and Figure 1, seven participants out of 10 recommended for amendment of the Fifth Schedule, Article 6(3) of the Nigerian constitution (1999 as amended).

However, one of these seven participants recommended for outright removal of the constitutional provision, that is, Fifth Schedule, Article 6(3), while the remaining six participants shared the view that the Constitution of Nigeria 1999 (as amended) should be further amended to provide for a given monetary value of gifts allowable in the public service of Nigeria. The subthemes that emerged from the six participants' recommendations were monetary value of $1100-12,000$, $\$ 2,100-\$ 5,000$, and $\$ 5,100-10,000$. There were 24 mentions from participant interviews containing the theme of policy recommendations for allowable monetary value of gifts. Majority of the respondents representing $50 \%$ recommended allowable monetary value between $\$ 5,100$ and $\$ 10,000$ or equivalent of equivalent of between $\$ 14$ and $\$ 27$ (guided by the prevailing parallel market rate of $\$ 365$ per $\$ 1$ 
USD as of March 2018), while other categories of participants (30\% and $20 \%$, respectively) recommended $\$ 2,100-\$ 5,000$ and $\$ 100-000$. Table 4 summarizes the results.

Table 4. Summary of Results of the Study

\begin{tabular}{|c|c|}
\hline $\begin{array}{l}\text { Categories of } \\
\text { Perceptions }\end{array}$ & Emergent Subthemes \\
\hline \multicolumn{2}{|l|}{ Research Question 1} \\
\hline $\begin{array}{l}\text { Perceptions of the } \\
\text { practice of gift } \\
\text { giving generally }\end{array}$ & $\begin{array}{l}\text { The perceptions of the cultural practice of unrestricted gift } \\
\text { giving in the public service of research setting was } \\
\text { considered by the study participants as negative and } \\
\text { unethical. }\end{array}$ \\
\hline \multicolumn{2}{|r|}{ Uiverituar. } \\
\hline $\begin{array}{l}\text { Perceptions of the } \\
\text { nature of } \\
\text { association } \\
\text { between } \\
\text { unrestricted } \\
\text { public service gift } \\
\text { giving and } \\
\text { integrity }\end{array}$ & $\begin{array}{l}\text { The perceptions of the nature of association between the } \\
\text { practice of unrestricted public service gift giving and } \\
\text { integrity of the public servants was unfavorable. }\end{array}$ \\
\hline \multicolumn{2}{|l|}{ Research Question 3} \\
\hline $\begin{array}{l}\text { Perceptions of } \\
\text { effects of the } \\
\text { practice of gift } \\
\text { giving }\end{array}$ & $\begin{array}{l}\text { The perceptions of effects of the cultural practice of } \\
\text { unrestricted gift giving on the productivity of the public } \\
\text { service was that it lowers productivity, impairs national } \\
\text { security, promotes mediocrity at the expense of excellence, } \\
\text { negatively affects the ethical content of an organization, } \\
\text { and provides a window of opportunity for corruption. }\end{array}$ \\
\hline \multicolumn{2}{|l|}{ Research Question } \\
\hline \multicolumn{2}{|l|}{3.1} \\
\hline $\begin{array}{l}\text { Perceptions of } \\
\text { policy } \\
\text { recommendations }\end{array}$ & $\begin{array}{l}\text { The perceptions of policy recommendations to address } \\
\text { problems that may be associated with the cultural practice } \\
\text { of unrestricted gift giving in the public service of the } \\
\text { research setting was amendment of the Fifth Schedule, } \\
\text { Part } 1 \text {, Article } 6 \text { (3) of the Nigerian constitution (1999, as } \\
\text { amended) to provide for a restricted monetary value of } \\
\text { gifts. }\end{array}$ \\
\hline \multicolumn{2}{|l|}{$\begin{array}{l}\text { Research Question } \\
3.2\end{array}$} \\
\hline $\begin{array}{l}\text { Perceptions of } \\
\text { Policy } \\
\text { recommendations } \\
\text { for allowable } \\
\text { monetary value of } \\
\text { gifts }\end{array}$ & $\begin{array}{l}\text { The perceptions of policy recommendations for allowable } \\
\text { monetary value of gifts was } \$ 5,100-10,000 \text { (i.e., } \\
\text { equivalent to } \$ 14-\$ 27 \text { USD). }\end{array}$ \\
\hline
\end{tabular}




\section{Discussion}

\section{Policy Recommendations}

Central question and its inter-related follow-up questions sought the perceptions of CSO leaders on the cultural practice of unrestricted gift giving in the public service of a major territory in Nigeria in relation to the integrity of the public servants. Results suggested the following:

1. The perceptions of the cultural practice of unrestricted gift giving in the public service of a major territory in Nigeria were negative and unethical.

2. The perceptions of the nature of association between the practice of unrestricted public service gift giving and integrity of the public servants was unfavorable.

3. The perceptions of effects of the cultural practice of unrestricted gift giving on the integrity of public servants/productivity of the public service was that it lowers productivity, impairs national security, promotes mediocrity, negatively affects the ethical content of an organization, and provides window of opportunity for corruption.

4. The perceptions of policy recommendations to address problems that may be associated with the cultural practice of unrestricted gift giving in the public service of the major territory in Nigeria was amendment of the Fifth Schedule, Article 6(3) of the Nigerian constitution (1999, as amended) to provide for a restricted monetary value of gifts, and

5. The perceptions of policy recommendations for allowable monetary value of gifts were $\$ 5,100-\$ 10,000$ (i.e. equivalent of $\$ 14-\$ 27$ USD) or average of $\$ 7,800$ (\$21.5 USD).

Against this backdrop, the Nigerian policy makers will do well to take necessary steps to amend the constitution to reduce the amount of unrestricted gift giving. It is hoped that this measure, when implemented, would help to minimize the tendency for gifting in the public service so that the integrity of the public servants will not be compromised. It will help Nigeria, and public-sector workers in other counties, to refrain from practicing ethical relativism in public service ethics of gift giving. Results of this study support Leisinger's (2015) conclusion that this practice leads to dysfunctional work ethos including ethical failure.

Nigerian policy makers, along with the larger culture, should pay close attention to the recommendations of Hansen's (2012) study that Nigeria needs to show seriousness in fighting corruption and comply with international standard yardsticks for socioeconomic evaluations to improve on its international reckoning and be able to attract direct foreign investment.

Anticorruption strategies such as whistle-blowing, ethics education, stringent gift giving legislation, accountability and transparency as well as good governance that are antidotes for corruption, should be put in place (Oyamada, 2015). Ethical programs that emphasize extrinsic values at the expense of intrinsic values are bound to fail (Stucke, 2014), while incompetent leadership and ethically tolerant policies should be avoided as they breed corruption (Prenzler, Beckley, \& Bronitt, 2013).

\section{Implications for Social Change}

The findings of this study have the potential to create positive social change for the public service of Nigeria in implementing public policy efficiently, effectively, democratically, transparently, and accountably without public market failure (Salmon, 1995). It may also help guide other communities in learning from the Nigerian experience. This is because the findings complement existing data to increase the understanding of the implication of the cultural practice of unrestricted gift giving in the public service for the integrity of public servants. This will also equip policy makers with needed information to reinforce extant gift giving public policy. Knowing that public office is public trust, 
and that its legitimacy depends on public confidence and support, this study provides the necessary policy checks and balances needed for a public administrator to avoid market failure in delivering public goods and services in line with public policy guidelines.

By evaluating policy outcome of the cultural practice of unrestricted gift giving and integrity of the public servants through the lens of leaders of civil society organizations, the study emphasizes the thesis of John Locke's social contract theory (Barker, 1950) that political power belongs to the people and that government officials or representatives hold this power in trust for the people, and this power should be exercised to meet the yearnings and aspirations of the people. Government failure, which explains a situation where public markets are typified by incompetence in delivering public goods and services, negates public sector objectives (David \& Aidant, 1992). The findings of the study impact the ethics of gifting and integrity of the public servants and equips Nigerian policy makers to understand better that the what and why we study public policy are to effectively address the causes and consequences of public policy as they relate to policy demands, policy decisions, policy statements, policy outputs, and policy outcomes.

\section{Areas of Future Research}

The findings from this study promote additional investigation on the cultural practice of unrestricted gift giving in the public service in relation to the integrity of the public servants. The study probed perceptions of the practice; perceptions of nature of association between unrestricted gift giving practice and integrity of public servants, perceptions of effect of the practice, and perceptions of the policy recommendations to address any identified problems that may be associated with the practice. It did not probe the actual effect of the practice on integrity of the public servants and or on productivity of the public service. This requires a more vigorous research with larger sample size and testing of hypotheses to establish relationship between relevant variables.

Additionally, one of the findings of this study in respect of policy recommendation was amendment of the Fifth Schedule, Article 6(3) of the Nigerian Constitution to provide for a restricted monetary value of gift that may not compromise the integrity of the public servants. Sequel to this, participants recommended between $\$ 5,100$ and $\$ 10,000$. This recommendation is in tandem with the provisions of Do It Right Handbook of the U.S. Department of Justice (2013), which is an adaption from a handbook released by the Office of Government Ethics. This regulation put a ceiling to allowable gift giving in the public service to be not more than $\$ 20$ USD (see https://www.justice.gov/jmd/do-it-right). This is the basis for allowing tipping in the U.S. public service, provided it does not go beyond $\$ 20$. However, Torfason, Flynn, and Kupor (2012) and Hartman and Ramamoorti (2016) found a positive relationship between an altruistic act of tipping and an immoral act of bribery in the public service. According to them, both practices are guided by the norms of exchange, which demand reciprocity. The scholars, therefore, argue for outright removal of any gifting in the public service. This is also the background upon which the U.K. Bribery Act of 2010 prohibits any form of gifting in the public service. Between these two practices-that is, (a) restricted monetary value of a gift to a modest amount that may not compromise integrity of public servants and (b) outright restriction of gifting in the public service-which of them will be more effective in safeguarding the integrity of the public servant? This calls for an answer.

There are also several research findings established in the literature that are well known in the field of public policy and administration but are contradicted in practice and in the literature of other fields of study. For example, the review of related literature suggests that possession of higher education is positively correlated to good ethical attitude and vice versa (Perry \& Isahuridu, 2013), but in practical terms in Nigeria, most monumental corrupt practices are committed by senior public 
officials (Global Witness, 2012; Oarhe, 2013) and "by well-placed men of questionable integrity" (Ejiofor, 1985, p. 7). Ohemeng (2015) suggested that policy learning is positively correlated to policy implementation, but the experiences garnered from implementations of public policy in Nigeria from its independence till present has not improved any policy outcome (Ijewereme, 2015). We call for further scientific investigation into these research claims with a view to establishing the veracity of these research findings in the Nigerian context.

\section{References}

Ayodele, F. O. (2014). Performance measurement and management. Lagos, Nigeria: National Open University, School of Business and Human Resources Management.

Barker, E. (1950). Social contract: Essays by Locke, Hume, and Rousseau. London, United Kingdom: Oxford University Press.

Bello, A. O. (2014). Gift giving, anti-bribery laws, and the Nigerian Constitution: Matters arising. Journal of African Law, 58, 278-302. doi:10.1017/S0021855314000102

Bello, J. B., \& Murtala, M. M. (2015). Public service in Nigeria: An overview of functions and code of conduct. Global Journal of Politics and Law Research, 3, 61-69.

Benson, J. K. (1982). A framework for policy analysis. In D. Rogers, \& D. Whitten (Eds.), Interorganizational co-ordination: Theory, research and implementation (pp. 137-176). Ames, Iowa: Iowa State University Press.

Bureau of Public Procurement. (2007). List of civil society organizations. Retrieved from http://www.bpp.gov.ng/index.php?option=com_joomdoc\&task=document.download\&path=\&It emid=569

Code of Conduct Bureau and Tribunal Act, CAP 56, LFN (1990). Retrieved from http://lawnigeria.com/LawsoftheFederation/CODE-OF-CONDUCT-BUREAU-ANDTRIBUNAL-ACT.html

Cohen, N. (2012). Policy entrepreneurs and the design of public policy conceptual framework and case of National Health Insurance Law in Israel. Journal of Social Research and Policy,3, $15-26$.

Constitution of the Federal Republic of Nigeria, Nigeria Law. (1999). Retrieved from https://www.nigeria-law.org/ConstitutionOfTheFederalRepublicOfNigeria.htm

David, L. W., \& Aidant, R. V. (1992). Policy analysis: Concepts and practice (2 ${ }^{\text {nd }}$ ed.). Englewood Cliffs, NJ: Prentice Hall.

Dion, M. (2013). Uncertainties and presumptions about corruption. Social Responsibility Journal, 9, 412-426. doi:10.1108/srj-04-2012-0045

Ejiofor, P. N. O. (1985). Management styles in a result oriented services: Managing people for desired results (Public Service Lecture Series, No.1). Imo, Nigeria: Imo State Government.

Ejionye, U. A. (1984). Industrial relations of the 1980s and 1990s. In P. N. O. Ejiofor \& V.A. Aniagolu (Eds.), Managing the Nigerian worker (p. 195). Lagos, Nigeria: Longman.

Global Witness. (2012). Global witness submission to international development select committee inquiry on tax and development. Retrieved from http://www.globalwitness.org/sites/default/files/library/Global\%20Witness\%20submission\%20 to\%20IDC\%20Tax\%20Inquiry\%206\%20Feb\%202012.pdf 
Hanf, K. (1978). Introduction. In K. Hanf \& F. W. Scharpt (Eds.), Intergovernmental policy making: Limits to Coordination and central control (pp. 1-15). London, United Kingdom: Sage.

Hansen, H. R. (2012). The power of performance indices in the global politics of anti-corruption. Journal of International Relation and Development, 15, 506-531. doi:10.1057/jird.2011.18

Hartman, J. D., \& Ramamoorti, S. (2016). Public corruption: Causes, consequences and countermeasures. Journal of Government Financial Management, 65, 42-47.

Ijewereme, O. B. (2013). An examination of anti-corruption crusades in Nigeria: Issues and challenges. The Quarterly Journal of Administration, 33, 108-127.

Ijewereme, O. B. (2015). Anatomy of corruption in the Nigeria public sector: Theoretical perspectives and some empirical explanations. Thousand Oaks, CA: Sage. doi:10.117712158244015581188

Independent corrupt practices and other related offences. (2000). Act No. 5.

Jones, V., \& Bezuidenhout, H. (2014). Best practices to regulate gifts in the South African public sector. Administratio Publica, 22, 68-92.

Kems, P., \& Wood, N. O. (2015). The gift: In an effort to show they mean business when it comes to ethics, legislatures continue to shore up laws that limit gifts from lobbyists. National Conference of State Legislatures, 41, 20-22.

Kim, C. (2014). Anti-corruption initiatives and e-government: A cross-national study. Public Organization Review, 14, 385-396. doi:10.1007/s11115-013-0223-1

Krambia-Kapardis, M. (2014). Perceptions of political corruption as a function of legislation. Journal of Financial Crime, 21, 44-55. doi:10.1108/jfc-04-2013-0025

Leisinger, K. M., (2015). Corporate responsibility in a world of cultural diversity and pluralism of values. Journal of International Business Ethics, 8, 9-31.

Markovska, A., \& Adams, N. (2015). Political corruption and money laundering: Lessons from Nigeria. Journal of Money Laundering Control, 18, 169-181. doi:10.1108/jmlc-10-2014-0040

Mazmanian, D. A., \& Sabatier, P. A. (1983). Implementation and public policy. Glenview, IL: Scott, Foresman.

Mentoor, J. (2010). Managing gifts in the public service, South Africa. PSC News. Retrieved from www.PSC.Gov.za/news/letter/doc./2010/pscnews.pdf

Mettler, S., \& SoRelle, M. (2014). Policy feedback theory. In P. A. Sabatier \& C. M. Weible (Eds.), Theories of the Policy Process (3rd ed.; pp. 151-181). Boulder, CO: Westview Press.

Moon, K. (2016).The influence of South Korean NGOs on state aid policy. Asian Perspective, 40, 217298.

Oarhe, O. (2013). Tonic or toxin? The state, neo-patrimonialism, and anticorruption efforts in Nigeria. The Korean Journal of Policy Studies, 28, 111-134. Retrieved from http://sspace.snu.ac.kr/bitstream/10371/82819/1/6\%201t700483.pdf

Ohemeng, F. L. K. (2015). Civil society and policy making in developing countries: Assessing the impact of think tanks on policy outcomes in Ghana. Journal of Asian and African Studies, 50, 667-682. doi:10.1177/0021909614535917

Okonkwo, C. (Ed.). (1992). Okonkwo \& Naish: Commercial law in Nigeria. Abuja, Nigeria: Spectrum Book.

Opejobi, S. (2016, September 5). Nigeria one of the poorest countries in the world, over 80m living below poverty line: U.N. report. Daily Post. Retrieved from 
http://dailypost.ng/2016/09/05/nigeria-one-poorest-countries-world-80m-living-poverty-lineun-report/

Osipian, A. L. (2012). Loyalty as rent: Corruption and politicization of Russian universities. The International Journal of Sociology and Social Policy; 32, 153-167. doi:10.1108/01443331211214730

Osipitan, T., \& Oyewo, O. (1999). Legal and institutional framework for combating corruption in Nigeria. In E. O. Akrunki (Ed.), Unilag readings in law (p. 258). Lagos, Nigeria: Faculty of Law, University of Lagos.

Oyamada, E. (2015). Anti-corruption measures the Japanese way: Prevention matters. Asian Education and Development Studies, 4, 24-50. doi:10.1108/aeds-10-2014-0047

Pierson, P. (1993). When effect becomes cause: Policy feedback and political change. World Politics, 45, 595-628. doi:10.2307/2950710

Prenzler, T., Beckley, A., \& Bronitt, S. (2013). Police gifts and benefits scandals: Addressing deficits in policy, leadership and enforcement. International Journal of Police Science and Management, 15, 294-304. doi:10.1350/ijps.2013.15.4.319

Salmon, I. M. (1995). Partners in public service: Government-nonprofit relations in the modern welfare state, Political Science Quarterly, 110, 648. doi:10.2307/2151902

Stucke, M. E. (2014). In search of effective ethics and compliance programs. Journal of Corporation Law, 39, 769. doi:10.2139/ssrn.2366209

Szto, M. (2016). Chinese gift giving, anti-corruption law, and the rule of law and virtue. Fordham International Law Journal, 39, 591.

The Corrupt Practices and Other Related Offences Act of 2000 (Act No. 5).Retrieved from http://icpc.gov.ng/wp-content/uploads/downloads/2012/09/CORRUPT-PRACTICES-ACT2010.pdf

Torfason, M .T., Flynn, F. J., \& Kupor, D. (2012): Here is tip: Pro-social gratuities are linked to corruption. Social Psychological and Personality Science 4, 348-354. doi:10.1177/1948550612454888

Trading Economics. (2017). Nigeria's GDP per capita income between 1960-2015. Retrieved from http://www.tradingeconomics.com/nigeria/gdp-per-capita

Transparency International. (2016). Corruption perceptions index. Retrieved from http://www.transparency.org/news/feature/corruption_perceptionss_index_2016

U.S. Department of Justice. (2013). Do it right handbook. Retrieved from https://www.justice.gov/jmd/do-it-right

Waziri, F. (2010). Corruption and governance challenge. Nigeria Conference Proceedings, Monograph Series, No. 7, CLEEN Foundation, Abuja, Nigeria.

World Bank Group Enterprise Survey. (2014). Nigeria. Retrieved from http://www.enterprisesurveys.org/data/exploreeconomies/2014/nigeria 
The Journal of Social Change, sponsored by Walden University, welcomes manuscripts focusing on interdisciplinary research in social change that improves the human condition and moves people, groups, organizations, cultures, and society toward a more positive future.

Walden University Publishing: http://www.publishing.waldenu.edu 